\title{
Works on multi- and intercultural education published in Poland in 2020
}

Baraniuk, T. ed. 2020. Bojkowszczyzna: pogranicze czasów i przestrzeni. Warszawa: Wydawnictwo DiG.

Brejdak, J. 2020. Zrozumieć Innego. Próba zrozumienie Innego w fenomenologii, hermeneutyce, filozofii dialogu i teorii systemu. Kraków: Universitas. Chalupa, A., Karczewska, A.M., Kilinc, D. and Foulds, P. eds. 2020. Doświadczenie migracji: ujęcia interkulturowe i interdyscyplinarne. Białystok: Książnica Podlaska im. Łukasza Górnickiego.

Czajka, A. 2020. Kultura jako rozmowa: problemy porozumienia międzykulturowego i międzyreligijnego. Warszawa: Wydawnictwo Naukowe Uniwersytetu Kardynała Stefana Wyszyńskiego.

Czepil, B. and Opioła, W. 2020. Ethnic diversity and local governance quality: the case of Opole Province in Poland. Berlin: Peter Lang.

Drejer, F. 2020. Pogranicze polsko-czeskie w aspekcie edukacji szkolnej. Jelenia Góra: Karkonoska Państwowa Szkoła Wyższa w Jeleniej Górze.

Drozd, R. and Halczak, B. eds. 2020. Ukraińcy i ich sqsiedzi na przestrzeni wieków: polityka, gospodarka, religia, kultura i życie codzienne. Olsztyn: Uniwersytet Warmińsko-Mazurski w Olsztynie. Wydział Teologii.

„Edukacja Międzykulturowa” 2020, nr 1 (12).

„Edukacja Międzykulturowa” 2020, nr 2 (13).

Fiszbak, J. ed. 2020. Szkoła i polonistyka szkolna wobec przemian XXI wieku. Łódź: Wydawnictwo Uniwersytetu Łódzkiego.

Frączek, P. and Karolczuk, J. 2020. Na pograniczach: dylematy spoteczne $i$ kulturowe pogranicza. Sanok: Państwowa Wyższa Szkoła Zawodowa im. Jana Grodka, Polskie Towarzystwo Historyczne.

Gajowniczek, Z.T. and Khachatryan, R. eds. 2020. Wartości historyczno-kulturowe ojczystego kraju: międzynarodowy polsko-armeński projekt edukacyjny. Latowicz: Zespół Szkół w Latowiczu.

Glondys, D. and Bednarczyk, M. 2020. Komunikacja międzykulturowa albo lepiej nie wychodź z domu. Kraków: Wydawnictwo Uniwersytetu Jagiellońskiego.

Granberg, S.J. 2020. Poza podręcznikiem: spostrzeżenia kulturowe w środowisku nauczania integracji języka szwedzkiego w Finlandii. Kraków: Ridero. 
Jasiński, Z. and Nowak, Z.M. eds. 2020. Jakość i styl życia oraz plany życiowe i tożsamość kulturowa mieszkańców polsko-czeskiego pogranicza po przyjęciu Polski i Czech do Unii Europejskiej. Kraków: Wydawnictwo PETRUS. Klim-Klimaszewska, A. ed. 2020. Uniwersalizm w edukacji społeczeństwa globalnego. Siedlce: IWN IKRiBL.

Kluczwajd, K. and Pszczółkowski, M. eds. 2020. Torunia przestrzeń wspólna: wielokulturowe miasto z cezura $i$ bez cezury 1920 roku. Toruń: Toruński Oddział Stowarzyszenia Historyków Sztuki.

Kochanowska, E. and Miczka-Pajestka, M. eds. 2020. Transformacja przestrzeni edukacyjnej a tożsamość ucznia i nauczyciela: wybrane problemy. Bielsko-Biała: Akademia Techniczno-Humanistyczna w Bielsku-Białej.

Kożyczkowska, A. and Szczepska-Pustkowska, M. eds. 2020. Mniejszości etniczne i ich pogranicza. Szkice tożsamościowe. Gdańsk: Uniwersytet Gdański.

Kwiatek, A. and Machelski, Z. eds. 2020. Europa Środkowo-Wschodnia jako obszar wielu kultur i polityk: studia historyczne i politologiczne ofiarowane Profesorowi Nikotajowi Iwanowowi. Opole: Uniwersytet Opolski.

Lipelt, R. ed. 2020. Na pograniczach: instytucje i ludzie pogranicza. Sanok: Państwowa Wyższa Szkoła Zawodowa im. Jana Grodka, Polskie Towarzystwo Historyczne.

Lubczyk, I. 2020. Łemkowszczyzna (od końca XIX do lat trzydziestych XX wieku): etnopolityka i tożsamość. Krosno: Stowarzyszenie Pod Karpatami.

Ławrynow, D. 2020. Swoi wśród obcych: tożsamość Kozaków kubańskich bytego Wojska Czarnomorskiego oraz Kozaków kazachstańskich (na podstawie tekstów folklorystycznych). Kraków: Instytut Języka Polskiego PAN.

Marszałek-Kawa, J. and Górnikiewicz, M. eds. 2020. Różne oblicza Azji: między Azją Wschodniq a Indiami. Toruń: Wydawnictwo Adam Marszałek.

Murzyn, A. and Śliwerski, B. 2020. Irlandia: Zielona Wyspa międzykulturowej oraz egalitarnej edukacji i opieki. Kraków: Oficyna Wydawnicza „Impuls”.

Nawolska, B., Pawlak, B. and Żmijewska, E. 2020. Wybrane konteksty wspótczesnej edukacji wczesnoszkolnej: przedsiębiorczość, neuroedukacja, międzykulturowość. Kraków: Wydawnictwo Naukowe Uniwersytetu Pedagogicznego.

Nikitorowicz, J. 2020. Edukacja międzykulturowa w perspektywie paradygmatu wspótistnienia kultur. Białystok: Wydawnictwo Uniwersytetu w Białymstoku. 
Nowicka, E. and Žanaev, A. 2020. Po obu stronach Ononu: Buriaci na pograniczu rosyjsko-mongolskim. Warszawa: Collegium Civitas Press.

Nowosad, I. and Tomasik-Abdelsamie, K. 2020. Przedszkola w Niemczech. Między siła tradycji a wyzwaniami przyszłości. Kraków: Oficyna Wydawnicza „Impuls”.

Ogrodzka-Mazur, E., Błahut, G. and Piechaczek-Ogierman, G. eds. 2020. Pedagogika a etnologia i antropologia kulturowa: wspólne obszary badań. Poznawanie kultur: ku edukacji antropologicznej i międzykulturowej. Toruń: Wydawnictwo Adam Marszałek.

Olszewska, D. 2020. Mniejszość chińska na Bali: studium tożsamości. Toruń: Oficyna Wydawnicza Mirosław Jacek Kucharski.

Opiłowska, E.J., Dębicki, M., Dolińska, K., Kajta, J., Kurcz, Z., Makaro, J. and Niedźwiecka-Iwańczak, N. eds. 2020. Studia nad granicami i pograniczami: leksykon. Warszawa: Wydawnictwo Naukowe „Scholar”.

Owsiany, T. 2020. Kraj naprawdę i na niby: reportaże z Gujany Francuskiej. Warszawa: Muza Sport i Turystyka.

Pamuła, A. 2020. Wrzenie: Francja na krawędzi. Warszawa: Wydawnictwo Agora.

Panek, B. 2020. U nas każdy jest prorokiem: o Tatarach $w$ Polsce. Wołowiec: Wydawnictwo Czarne.

Pawlik, J.J. 2020. Ku nowej kulturze: zmagania adaptacyjne. Olsztyn: Uniwersytet Warmińsko-Mazurski w Olsztynie.

Pękowska, M. 2020. Wielokulturowość w praktyce surdopedagogicznej w Polsce w latach 1918-1939. Kraków: Oficyna Wydawnicza „Impuls”.

Sacharczuk, J. 2020. Pamięć społeczna z perspektywy edukacji regionalnej: analiza doświadczeń biograficznych białostoczan pochodzenia polskiego $i \dot{z y d o w s k i e g o ~ u r o d z o n y c h ~ p r z e d ~ I I ~ w o j n q ~ s ́ w i a t o w a ̨: ~ s t u d i u m ~ p o r o ́ w n a w c z e ~}$ pamięci społecznej licealistów z Polski i Izraela. Białystok: Wydawnictwo Uniwersytetu w Białymstoku.

Singer, I.J. ed. 2020. Na obcej ziemi. Lublin: Fame Art.

Siwor, D. ed. 2020. EtnoCuda: elementarz folkloru polsko-słowackiego pogranicza. Bielsko-Biała: Regionalny Ośrodek Kultury w Bielski-Białej.

Stolarczyk, B. and Merkelbach, Ch. eds. 2020. Języki odziedziczone - polski, rosyjski i turecki w spoteczeństwie międzykulturowym $i$ wielojęzycznym. Düren: Shaker Verlag.

Wojdon, J. 2020. Czytając o wieloetniczności. Wrocław: Uniwersytet Wrocławski.

Wróblewski, B. and Janicki, Ł. eds. 2020. Na pograniczu narodów i kultur: 
Polska - Europa - Ameryka. Warszawa - Lublin: Spółdzielnia Wydawnicza "Czytelnik”, Wschodnia Fundacja Kultury „Akcent”.

Żelazkowska, M.I. and Czarnecka, M. 2020. Sapientia et adiumentum: edukacja religijna dzieci z niepetnosprawnościa intelektualnq $w$ stopniu lekkim. Płock: Wydawnictwo Naukowe Mazowieckiej Uczelni Publicznej w Płocku.

Collected by Barbara Grabowska 